Dariusz Kasprzycki ${ }^{1}$

\title{
KONTROWERSJE WOKÓŁ ZDOLNOŚCI PATENTOWEJ WYNALAZKÓW BIOTECHNOLOGICZNYCH
}

\section{Uwagi ogólne}

Dyskusja nad wynalazkami biotechnologicznymi rozpoczęła się szerzej w latach 80. XX wieku, koncentrując się nad wytyczeniem linii pomiędzy patentowalnymi i niepatentowalnymi rozwiązaniami. $Z$ powodzeniem można powiedzieć, że trwa do dzisiaj, mimo że nikt nie ma już wątpliwości co do możliwości patentowania organizmów żywych. Zwyciężyła więc droga wyznaczona w słynnym orzeczeniu przyznającym ochronę patentową wszystkiemu, co „człowiek stworzył pod słońcem". ${ }^{2}$ Wydaje się, że jedyne, co pozostało prawu patentowemu, to możliwość tę ograniczać poprzez albo powoływanie się na wartości wyższego rzędu, albo restrykcyjną interpretację przesłanek patentowalności.

Początkowo uważano, że organizmy żywe nie mogą zostać opatentowane. Stopniowo jednak upadały kolejne bariery w tym zakresie. „Stare” wynalazki biotechnologiczne posługiwały się mechanizmem selekcji, izolacji i hodowli organizmów, a sama dziedzina została określona mianem biotechnologii ,intuicyjnej”. ${ }^{3}$ Te wynalazki również wywoływały kontrowersje, jednak głównie z powodu istniejącej dychotomii $\mathrm{w}$ zakresie ochrony odmian roślin w prawie własności przemysłowej i wyłączeń odnośnie ras zwierząt pod zakresu patentowalności. ${ }^{4}$

„Nowe" wynalazki biotechnologiczne posługują się technologiami obejmującymi modyfikację informacji genetycznej. W tym zakresie patentuje się nie tylko sposoby otrzymywania produktów biotechnologicznych, ale i same produkty w nich uzyskiwane. Już relatywnie od dawna udziela się patenty na organizmy samoist-

Doktor, Katedra Prawa Własności Intelektualnej Wydziału Prawa i Administracji Uniwersytetu Jagiellońskiego.

"Anything under the sun that is made by man" Diamond przeciwko Chakrabarty, 447 US 303,309 (1980).

Przykładem będzie tu chociażby wynalazek, który otrzymał Ludwik Pasteur na oczyszczone drożdże do produkcji piwa w 1873 roku.

4 Zob. przegląd historycznego orzecznictwa M. du Vall, Prawo patentowe, Warszawa 2008, s. 360 i n. 
nie występujące w naturze i zmodyfikowane przez człowieka oraz organizmy takie same, jak występujące naturalnie, ale wyizolowane lub stworzone sztucznie. ${ }^{5}$

Dla porządku należy wskazać właściwe ramy prawne, które wyznaczone są przez ustawę z dnia 30 czerwca 2000 r. - Prawo własności przemysłowej, ${ }^{6}$ w szczególności art. 24-29 ogólnie regulujące zdolność patentową oraz art. 931-937 zawierające przepisy szczególne, stanowiące transpozycję unijnej dyrektywy 98/44/WE w sprawie ochrony prawnej wynalazków biotechnologicznych. ${ }^{7} \mathrm{~W}$ stosunku do patentów europejskich będą to przepisy Konwencji o udzielaniu patentów europejskich ${ }^{8}$ (art. 52-57) oraz przepisy szczególne dotyczące wynalazków biotechnologicznych zawarte w regulaminie wykonawczym. ${ }^{9} \mathrm{Na}$ poziomie konwencji ponadregionalnych należy wskazać na porozumienie TRIPS ${ }^{10}$ potwierdzające możliwość patentowania mikrorganizmów i procesów mikrobiologicznych (art. 27.3 (b)). W wymienionych regulacjach mamy grupę przepisów zawierających wyłączenia patentowania, znajdującą zastosowanie do wynalazków biotechnologicznych. Ze względu na ich częste w nich odniesienia do norm pozaprawnych (moralność, porządek publiczny, dobre obyczaje) duże znaczenie będą posiadać przepisy wielu aktów prawa międzynarodowego wspomagającego konkretyzację wskazanych norm. ${ }^{11}$

Po drugie, należy również nadmienić, że zakres wynalazku biotechnologicznego wyznacza nie odniesienie do definicji biotechnologii, lecz definicja materiału biotechnologicznego zawarta w dyrektywie biotechnologicznej, czyli w uproszczeniu - materiału zawierającego informację genetyczną i wykazującego zdolność do samoreprodukcji.

\section{Przesłanki patentowalności}

Wynalazki biotechnologiczne podlegają tym samym wymaganiom względem patentowalności, jak i pozostałe, co potwierdza art. $93^{1}$ prawa własności przemysłowej. Najciekawsze wydaje się więc właśnie to, w jaki sposób wynalazki biotech-

Zob. H. Żakowska-Henzler, Wynalazek biotechnologiczny. Przedmiot patentu, Warszawa 2006.

Tekst jedn. Dz.U. z 2013 r. poz. 1410, dalej jako p.w.p.

Dyrektywa 98/44/WE z dnia 6 lipca 1998 r. w sprawie ochrony prawnej wynalazków biotechnologicznych, (Dz.U.UE.L.1998 Nr 213, poz. 13), dalej jako dyrektywa biotechnologiczna.

Konwencja o udzielaniu patentów europejskich (European Patent Convention - EPC) (Dz.U. z 2004 r. Nr 79, poz. 737), ze zmianami wprowadzonymi aktem rewidującym z dnia 29 listopada 2000 r., który wszedł w życie dnia 13 grudnia 2007 r. (Dz.U. z 2007 r. Nr 236, poz. 1736), dalej jako EPC.

Regulamin wykonawczy jest integralną częścią EPC, a przepisy szczególne dotyczące wynalazków biotechnologicznych są zawarte w rozdziale V, art. 26-34 i de facto są zaczerpnięte z dyrektywy biotechnologicznej. Zob. www.epo.org/law-practice/legal-texts/html/epc/2013/e/ma2.html (data dostępu: 11.09.2015 r.).

Porozumienie w sprawie Handlowych Aspektów Praw Własności Intelektualnej, Obwieszczenie Ministra Spraw Zagranicznych z 12 lutego 1996 r. w sprawie publikacji załączników do Porozumienia ustanawiającego Światową Organizację Handlu (WTO), Dz.U. z 1996 r. Nr 32, poz. 143.

Będą to m.in. Karta praw podstawowych UE (Dz.U. z 2009 r. Nr 203, poz. 1569);Konwencja Rady Europy o ochronie praw człowieka i godności istoty ludzkiej wobec zastosowań biologii i medycyny (Europejska Konwencja Bioetyczna), CETS No. 164; Konwencja o ochronie praw człowieka i podstawowych wolności (Dz.U. z 1993 r. Nr 61, poz. 284 z późn. zm.). 
nologiczne wpłynęły na interpretację przesłanek ogólnych. Mogłoby się zdawać, że istota wynalazków biotechnologicznych opartych na inżynierii genetycznej sprowadza problem patentowalności na poziom właściwy dla związków chemicznych, którymi geny są ze swej istoty. Natomiast fakt, że wynalazek dotyczy materii ożywionej nie ma znaczenia. ${ }^{12}$ Nie jest jednak możliwe stosowanie tu pełnej analogii ze względu na fakt, że najistotniejszą cechą DNA jest zdolność do kodowania białek, a więc sama jego struktura nie posiada wartości decydującej przy ocenie zdolności patentowej. Ponadto zastrzeżenia patentowe nie są redagowane w kategorii właściwej dla związków chemicznych, a odnoszą się do informacji genetycznej kodowanej w określonych genach. ${ }^{13}$ Oznacza to, że ocena patentowalności wynalazków biotechnologicznych nie może posługiwać się w pełni drogą interpretacji wykształconą na gruncie wynalazków chemicznych.

\subsection{Nowość}

Fundamentalna zasada systemu patentowego mówi o nowości odnoszonej do pojęcia „stan techniki” ocenianej w wymiarze globalnym. Co do zasady, nie budzi kontrowersji patentowanie sposobów uzyskiwania materiału biologicznego, w szczególności izolacji DNA. Pytanie, które w przypadku biotechnologii musiało się pojawić wcześniej czy później dotyczy dopuszczalności patentowania w kategorii produktu wynalazków obejmujących struktury już istniejące w naturze. Odpowiedź została udzielona $\mathrm{w}$ dyrektywie biotechnologicznej, za którą prawo własności przemysłowej powtarza, ${ }^{14}$ że ,za wynalazki biotechnologiczne, na które mogą być udzielane patenty, uważa się wynalazki stanowiące materiał biologiczny, który jest wyizolowany ze swojego naturalnego środowiska lub wytworzony sposobem technicznym, nawet jeżeli poprzednio występował w naturze". Stan techniki jest określony natomiast jako „wszystko to, co (...) zostało udostępnione do wiadomości powszechnej w formie pisemnego lub ustnego opisu, przez stosowanie, wystawienie lub ujawnienie w inny sposób" (art. 25 ust. 2 p.w.p.). W efekcie należy uznać, że o nowości lub jej braku nie przesądza fakt, że dane rozwiązanie istniało przed datą będącą miarodajnym punktem do oceny (datą pierwszeństwa), lecz to, czy publiczna wiedza o nim była dostępna. ${ }^{15}$

Jak zatem uzasadnia się nowość takich wynalazków? Po pierwsze, stan techniki obejmujący wszystko, co zostało udostępnione do wiadomości publicznej nie obejmuje tej informacji genetycznej, która choć istniejąca wcześniej nie była znana.

12 Stanowisko to było powszechnie akceptowane w początkowym okresie biotechnologii, E. Żakowska-Henzler, Wynalazek..., op. cit., s. 153 i n. Zob też orzeczenie w sprawie In re Bergy, "the fact that microorganisms are alive is a distinction without legal significance and that they should be treated under 101 no differently from chemical compounds", Ex parte Roslin Institute (Edinburgh), P.T.A.B., Appeal no. 2010-006828 (2013) at 18-19.

13 Por. Association for Molecular Pathology v. Myriad Genetics, Inc., USSC 12-398.

$14 \quad$ Art. $93^{2}$ ust. 1 pkt 1 i 2 p.w.p.

15 Powyższe potwierdza to chociażby stanowisko EPO zawarte w Wytycznych (Guideliness for Examination), których ostatnia wersja pochodzi z listopada 2014 r., https://www.epo.org/law-practice/legal-texts/guidelines.html (data dostępu: 11.09.2015 r.). 
Ta okoliczność miałaby jedynie znaczenie dla odmowy udzielenia patentu z uwagi na dokonanie odkrycia. Po drugie, $w$ ramach procesu izolacji lub syntezy otrzymuje się materiał genetyczny o innej nieco strukturze, niż istniejący w naturze. Dość obrazowo tłumaczy to proces otrzymywania tzw. komplementarnego DNA (cDNA), gdzie w wyniku oddzielenia jednej nici DNA do mRNA, a następnie odwrotnej transkrypcji do cDNA, otrzymuje się gen o takiej samej informacji genetycznej, ale pozbawiony struktur niekodujących (intronów). Produkt końcowy może spełniać te same funkcje, ale jego budowa jest inna od oryginału. Obecność genów w naturze nie antycypuje ich izolacji, ponieważ geny wyizolowane zawierające jedynie struktury kodujące są inne od naturalnych. ${ }^{16}$ Po trzecie, nowości wynalazku mającego za przedmiot DNA nie niweczy ujawnienie DNA w ramach zsekwencjonowania całego genomu ani jej zdeponowanie, ponieważ dostępność do informacji o tym materiale jest porównywalna do stanu, w jakim znajdował się w naturze. ${ }^{17}$ Zatem dostępność informacji o naturalnym produkcie (nawet $\mathrm{w}$ bankach genów ${ }^{18}$ ) nie niweczy automatycznie nowości, ponieważ niekoniecznie muszą być znane jego funkcje. Zatem, fakt poznania genomu ludzkiego nie stanowi przeszkody patentowania jego poszczególnych sekwencji. ${ }^{19}$ Tutaj objawia się właśnie odmienność traktowania wynalazków biotechnologicznych od związków chemicznych. Swoistym kryterium zdolności patentowej staje się więc szczegółowość ujawnionych informacji decydująca o jednoznaczności zdefiniowania związku oraz jednoznaczne wskazanie jego funkcji, co odzwierciedla specyfikę przedmiotu wynalazków biotechnologicznych. Reasumując, nowość w kategorii produktu niweczy brak różnic w zakresie zarówno struktury, jak i właściwości oraz funkcji w stosunku do związków istniejących w naturze.

\subsection{Poziom wynalazczy}

Najistotniejszy zarzut w zakresie niespełniania poziomu wynalazczego wynalazków biotechnologicznych dotyczy ich rutynowości. O wyniku decyduje bowiem tutaj ilość podejmowanych prób a nie twórczy element rozwiązania stanowiący o nieoczywistości. Dodatkowo, badania w zakresie inżynierii genetycznej posługują się wysoce skomputeryzowaną metodą dopasowywania sekwencji DNA, ${ }^{20}$ która usprawnia cały proces poprzez powtarzające się procedury. Stanowiskiem ograniczającym szeroką patentowalność jest uznanie, że w sytuacji, kiedy wynik jest przewidywalny i zależny jedynie od liczby prób (obvious to try), to należy odmówić ochrony patentowej. To podejście koresponduje z powszechnie akceptowaną zasadą, że poziomu wynalazczego nie spełniają wynalazki, których dokonanie ma charakter

\footnotetext{
Howard Florey/Relaxin, EPO Oposition Division 8 grudnia 1994, EPOR 541.

M. du Vall, Prawo patentowe..., op. cit., s. 372.

Kiren Amgen, EPO Oposition Division 21 listopada 1994, EPOR 629.

E. Żakowska-Henzler, Wynalazek..., op. cit., s. 154.

Computerised matching of DNA process. Zob W. Cornish, D. Llewelyn, T. Aplin, Intellectual Property: Patents, Copyright, Trade Marks and Allied Rights, London 2013, s. 908.
} 
pewny. ${ }^{21}$ Można argumentować, że rutynowość nie jest równa pewności, ale należy wziąć pod uwagę, że za wynalazki oczywiste uznaje się nie tylko te, których pewność otrzymania istnieje, ale także i te, które wynikają w sposób wyraźny lub logiczny ze stanu techniki. ${ }^{22}$

Drugim problemem jest tu kwestia osoby ,znawcy”, od której zależy ocena nieoczywistości. Powszechnie przyjmuje się, że chodzi tu o poziom przeciętnego specjalisty, co w przypadku wynalazków biotechnologicznych oznacza np. wykwalifikowaną osobę pracującą w jednej z dziedzin inżynierii genetycznej, ${ }^{23}$ a nie laureata nagrody Nobla. ${ }^{24}$ Można jednak zauważyć, że mimo założenia pewnej „przeciętności” poziomu wiedzy, dziedzina biotechnologii stawia wysokie wymagania względem ekspertów zatrudnianych w urzędach patentowych. Trudno jednak wskazać precyzyjnie właściwy poziom, zwłaszcza że hipotetyczna charakterystyka osoby znawcy różni się w wielu niuansach w zależności od krajowej linii orzeczniczej, w dodatku zmieniającej się w czasie. Np. może tu chodzić o poziom wiedzy i umiejętności, jaki można spotkać w zespołach badawczych pracujących w tej zaawansowanej dziedzinie. ${ }^{25}$ Może to też być osoba co najmniej doskonale znająca techniki sekwencjonowania białka (operowania mRNA) i posiadająca najlepsze wyposażenie badawcze. ${ }^{26}$ Dlatego też, próbując wskazać najbardziej reprezentatywne podejście można odwołać się do wytycznych EPO, zgodnie z którymi chodziłoby o przeciętnego praktyka (ordinary practitioner) świadomego wiedzy ogólnej w danym (aczkolwiek wąskim) zakresie, mającego dostęp do stanu techniki w zakresie wyznaczonym przez wynalazek oraz środki i możliwość rutynowej pracy. Nie są to jednak problemy właściwe tylko biotechnologii i można je spotkać w innych dziedzinach, jak np. nanotechnologia. Natomiast pewną specyfiką biotechnologii jest wykorzystywanie osiągnięć z innych dziedzin pokrewnych, co w przypadku osoby znawcy oznacza posiadanie wiedzy interdyscyplinarnej. W praktyce uważa się zatem, że jeżeli przedstawione rozwiązanie do oceny wymaga poszukiwania rozwiązania w innej dziedzinie, za znawcę uważa się specjalistę w tej dziedzinie właśnie. ${ }^{27}$

\subsection{Przemyslowa stosowalność}

Tradycyjnie uważana za mniej kontrowersyjną przesłankę patentowalności, w przypadku wynalazków biotechnologicznych nabrała dodatkowego znaczenia. Jednym z kontrowersyjnych punktów była początkowo interpretacja pojęcia ,prze-

21 Co nie oznacza, że tylko „pewne” wynalazki są uważane za oczywiste.

22 K.K. Singh, Biotechnology and Intellectual Property Rights. Legal and Social Implications, New Delhi-HeidelbergNew York-London 2015, s. 72.

23 Tak EPO w sprawie Genentech T 0455/91

24 Harvard Oncomouse, EPO T 60/89.

25 Tak sąd brytyjski w sprawie Genentech Inc.'S Patent, [1989] R.P.C. 147 (C.A.).

26 H. Żakowska-Henzler, Wynalazek..., op. cit., s. 179.

27 Zob. Wytyczne EPO oraz orzeczenie w sprawie Genentech T0455/91 lub Antiviral nucleosis / Wellcome Foundation cyt. za H. Żakowska-Henzler, Wynalazek..., op. cit., s. 177, gdzie problem ten wiązał się także z ustalaniem tzw. najbliższego stanu techniki. 
mysł", który rozumiany wąsko prowadziłby do zawężenia patentowalności wynalazków biotechnologicznych. Wymagano bowiem wskazania możliwości wdrożenia wynalazku w skali przemysłowej zorientowanego na odniesienie korzyści natury ekonomicznej. Tak restrykcyjne podejście, nieprzystające do specyfiki wielu rodzajów wynalazków zostało jednak porzucone i obecnie produkt, który może zostać użyty do zwalczania określonej choroby posiada przemysłowe zastosowanie, mimo iż w ogóle może nie być przedmiotem obrotu. ${ }^{28}$

Nie to jednak zagadnienie stało się najbardziej kontrowersyjne w przypadku wynalazków biotechnologicznych. Dość typową sytuacją w dziedzinie badań biotechnologicznych jest otrzymanie związków o nieokreślonym precyzyjnie zastosowaniu, ${ }^{29}$ co owocowało zgłoszeniami genów o nieznanych funkcjach. W takich przypadkach nie można było wykluczyć, że nie istnieje żadne zastosowanie, w związku z czym celowe stało się żądanie wskazania konkretnej formy, w jakiej wynalazek można zastosować. I tak, zgodnie z art. $93^{2}$ ust. 2 p.w.p. zgłoszenie wynalazku dotyczącego sekwencji lub częściowej sekwencji genu powinno ujawniać jego przemysłowe zastosowanie. ${ }^{30}$ Można na wstępie zadać pytanie, jakie znaczenie ma tego typu doprecyzowanie skoro, jak zawsze, możliwość przemysłowego zastosowania powinna wynikać z dokumentacji patentowej. ${ }^{31}$ Przepis ten posiadałby jedynie funkcję techniczną, nie zmieniając przesłanki ogólnej, a znajdując zastosowanie jedynie do oceny zdolności patentowej wynalazków biotechnologicznych. Rzeczywiste znaczenie tego zapisu posiada jednak sporą wartość, ponieważ przecina kontrowersje, czy samo wskazanie funkcji genu może być interpretowane jako forma przemysłowego zastosowania.

I tak, w sytuacjach nawet dokładnego wskazania samej substancji występującej w naturze, a otrzymywanej na drodze pewnego procesu, kiedy jego funkcja jest nieznana lub zbyt złożona i przez to niedokładnie poznana, np. kiedy żaden stan chorobowy nie został powiązany ze zmianą ilości (nadmiarem lub niedoborem) wskazanej substancji, to zdolność przemysłowa nie jest rozpoznana. ${ }^{32}$ Także zbyt szerokie wskazanie funkcji stoi na przeszkodzie udzielenia ochrony. ${ }^{33} \mathrm{~W}$ przeciwnym razie dochodziłoby do monopolizacji „czystych” wyników badań, których zastosowanie jest niewiadome. Z drugiej jednak strony pojawiają się także tendencje

Kwestia zysku (lub zamiaru jego odniesienia) nie powinna być okolicznością braną w tej kwalifikacji pod uwagę. Zob. uzasadnienie wyroku w sprawie Eli Lilly v. Human Genome Project, UK High Court 31 lipca 2008, EWHC 1903 Pat.

29 Zwłaszcza biorąc pod uwagę skomputeryzowany proces „maszynowego” sekwencjonowania DNA.

30 Punkt 24 preambuły dyrektywy biotechnologicznej precyzuje, że w „celu spełnienia kryterium przemysłowego stosowania niezbędne jest określenie, w przypadkach wykorzystania sekwencji lub częściowej sekwencji genu do produkcji białka lub części białka, jakie białko lub część białka jest wytwarzana albo jaką funkcję spełnia”. Jednocześnie punkt 23 stanowi, że sama sekwencja DNA, bez wskazania funkcji, nie zawiera żadnej informacji technicznej, a zatem nie jest wynalazkiem posiadającym zdolność patentową.

31 Nie powinno ulegać wątpliwości, że przemysłowa stosowalność powinna być odczytywana przez znawcę wyłącznie z dokumentacji patentowej. Dokumentacja powinna zatem wskazywać możliwość zastosowania z wystarczającą dozą szczegółowości.

32 BDPI Phosphatase v. Max Planck, T 0870/04 EPO.

33 Zymogenetics, EPO T 0898/05. 
odwrotne, dzięki temu, że przemysłowe zastosowanie może być jedynie uprawdopodobnione, co sprzyja wykształceniu bardziej liberalnego podejścia. W rezultacie wystarczyłoby, wskazanie zastosowania, które jest „rozsądnie wiarygodne”, a nawet może to być swego rodzaju „naukowe przypuszczenie". ${ }^{34}$ To kontrowersyjne stanowisko otwierałoby drogę do uznania zdolności patentowej szerokiej gamy produktów biotechnologicznych, których zastosowanie nie jest szczegółowo zdefiniowane, a jedynie w racjonalny sposób spodziewane.

Jeszcze innym specyficznym problemem pojawiającym się także w zakresie wynalazków biotechnologicznych są zastrzeżenia typu „reach-through". Ich pojawienie się związane jest z próbami opatentowania wyników badań na wczesnym etapie rozwoju (badań podstawowych, czy też tzw. upstream research), które posiadają potencjalne szerokie zastosowanie. Na poziomie technicznej redakcji zastrzeżenia reach-through dotyczą związku chemicznego (lub zastosowania tego związku) zdefiniowanego wyłącznie funkcjonalnie w odniesieniu do efektu technicznego, jaki wywiera na określoną cząsteczkę związku. Ta definicja nie precyzuje wprost skutków przyznania ochrony na tak zdefiniowany wynalazek, jednakże w istocie oznacza objęcie jego zakresem także substancji nieznanych, które mogą oddziaływać w sposób opisany w zastrzeżeniu. Wniosek patentowy zmierzałby zatem do patentowania czegoś, czego jeszcze nie wynaleziono.

\subsection{Kiedy pojawia się wynalazek biotechnologiczny? Charakter techniczny wynalazku}

Jednym z trudniejszych, aczkolwiek fundamentalnych pytan, jest wskazanie momentu, który decyduje o tym, że w procesie badawczym pojawia się określony funkcjonalnie wynik predestynujący do bycia już wynalazkiem, a nie - jeszcze odkryciem. Sfera wynalazków biotechnologicznych szczególnie rozmyła i tak skomplikowany już tutaj obraz. Być może wcale jednak nie jest konieczne, aby usilnie doszukiwać się tego momentu. Potwierdza to w pewnym sensie brak wykształconej definicji wynalazku w prawie patentowym, który od lat radzi sobie z tym problemem poprzez pośrednie wskazanie, jak rozumie pojęcie „wynalazek”. W jednej z opinii sądowych wskazano przykład wody, której wynaleźć nie można, ale można dokonać wynalazku w zakresie jej syntezy, czy też destylacji. ${ }^{35}$ Zdanie to miało posłużyć do ilustracji niedopuszczalności opatentowania w kategorii produktu związku, którego istnienie było znane, a w wyniku badań odkryto jego nieznaną właściwość. Nieco polemizując z tym poglądem można podnieść, że ten przykład jest zbyt oczy-

34 "Plausible" or "reasonably credible" claimed use, or an "educated guess", can suffice - wyrok w sprawie Human Genome Sciences Inc v Eli Lilly \& Co. Podobne rozstrzygnięcie zapadło w takiej samej sprawie przed EPO (EPO T0018/90). Co ciekawe ten sam stan faktyczny trafił „rykoszetem” przed TS UE (sprawa dotyczyła zasadności udzielenia SPC), który potwierdził w sposób ogólny możliwość funkcjonalnej definicji produktu w zastrzeżeniach patentowych.

35 You cannot invent water, although you certainly can invent ways in which it may be distilled or synthesised - Lord Mustill w sprawie Genentech Inc's Patent (1989). W tej sytuacji dopuszczalne jest jedynie udzielenie ochrony na proces. 
wisty i nie oddaje jakościowej różnicy pomiędzy zestawionymi tak przedmiotami ochrony (woda $v s$ otrzymana z niej substancja). Podnosi się jednak, że należy odrzucić intuicyjne rozumienie wynalazku, a samo badanie, czy coś jest wynalazkiem jest w gruncie rzeczy zbędne, zawsze bowiem, kiedy wykaże się spełnienie przesłanek patentowalności nie będzie możliwe odrzucenie wniosku o ochronę z uwagi na niedopasowanie do koncepcji wynalazku. ${ }^{36}$

W przypadku wynalazków biotechnologicznych kolosalne znaczenie posiada ogólne wyłączenie patentowalności odkryć. Punktem wyjścia staje się zatem wskazanie, że doszło do jakiegokolwiek przetworzenia materiału biologicznego występującego w naturze w wyniku ingerencji człowieka. Ramy prawne wyznaczone przez dyrektywę biotechnologiczną przyniosły wytyczenie arbitralnej granicy pomiędzy odkryciem a szczególnym rodzajem wynalazku zawierającym materiał biologiczny występujący w naturze. Warunkiem jest tutaj wyizolowanie z naturalnego środowiska lub wyprodukowanie sposobem technicznym (art. 3 ust. 2 dyrektywy biotechnologicznej). Obydwa wskazane zabiegi nie przynoszą dostatecznego uzasadnienia, dlaczego fakt izolacji lub wyprodukowania poza organizmem należy traktować jako wynalazek. Ich rezultatem będzie bowiem substancja już znana. Konieczność poniesienia istotnych nakładów niczego tutaj nie zmienia, ponieważ jest to okoliczność irrelewantna dla kwalifikacji na linii odkrycie - wynalazek. Uzasadnienia szuka się na wyższym poziomie szczegółowości w określaniu struktury materiału biologicznego. Nie ulega bowiem wątpliwości, jak już wyżej wskazano, że produkty otrzymane w wyniku izolacji lub pozaustrojowej produkcji nie są identyczne. ${ }^{37}$ Produkty uzyskane sposobem technicznym również nie będą tożsame. Właściwe pytanie, jakie należałoby postawić to takie, czy sama modyfikacja naturalnego materiału biologicznego oznacza przetworzenie wykluczające możliwość jego kwalifikacji jako odkrycia. Zwłaszcza jeśli modyfikacja prowadzi jedynie do „oczyszczenia” i to nie tyle oczyszczenia z elementów szkodliwych, ale elementów obojętnych z perspektywy funkcji, jaką sekwencja DNA ma pełnić.

Dyrektywa biotechnologiczna udzieliła odpowiedzi pozytywnej, a nawet poszła dalej, w gruncie rzeczy zezwalając na patentowanie odkryć polegających na sztucznym stworzeniu lub wyizolowaniu materiału biologicznego. ${ }^{38}$ Czytając ten przepis wprost, nie ma znaczenia, czy otrzymany materiał biologiczny różni się w jakikolwiek sposób od istniejącego wcześniej w naturze. Nie sposób jednak wykluczyć, że rozwój nauki doprowadzi do całkowitego zatarcia różnic pomiędzy produktem naturalnym a wyizolowanym lub zsyntetyzowanym. Nie jest to jedyny argument w tym kontekście. Najistotniejszy wydaje się fakt, że przedmiotem ochrony pozo-

36 Lord Hoffmann w sprawie Biogen Inc przeciwko Medeva plc (1997).

37 Sekwencje DNA nie są tym samym DNA, lecz tzw. komplementarnym DNA (cDNA) pozbawionym nieaktywnych elementów (intronów).

38 H. Żakowska-Henzler, Dostęp do procedur medycznych w świetle ochrony patentowej, (w:) L. Kondratiewa-Bryzik, K. Sękowska-Kozłowska (red.), Prawa człowieka wobec rozwoju biotechnologii, Warszawa 2013, s. 169. 
staje w efekcie ten element, który już wcześniej istniał. Modyfikacja, niezbędna dla oddzielenia go do odkrycia, nawet jeżeli istnieje nie staje się następnie istotnym elementem różnicującym zakres ochrony.

Nieco inaczej przedstawia się zagadnienie ,patentowalności odkryć” w prawie USA. Przede wszystkim brak jest w nim wyraźnej opozycji wynalazek - odkrycie (także z powodów „konstytucyjnych”), natomiast wynalazek nie może stanowić abstrakcyjnej idei, praw natury lub naturalnego zjawiska. ${ }^{39} \mathrm{Na}$ tle wyraźnej dopuszczalności patentowania genów zsyntetyzowanych lub wyizolowanych w Europie, ciekawie prezentuje się głośne orzeczenie Sądu Najwyższego USA w sprawie Myriad Genetics, ${ }^{40} \mathrm{~W}$ którym uznano, że naturalnie występujący segment DNA jest właśnie produktem natury przy jednoczesnym zastrzeżeniu możliwości patentowania cDNA, który już nie jest produktem występującym naturalnie.

Ciekawych argumentów w tym względzie dostarczają również przypadki klonowania zwierząt. Podstawowe pytanie, jakie tutaj pada, to pod jakimi warunkami kopia żywego organizmu nie będzie uważana za produkt natury. Organizm sklonowany pochodzący zawsze $\mathrm{z}$ naturalnego odpowiednika nie jest nowym organizmem $\mathrm{z}$ istotnie różniącą się charakterystyką od swego naturalnego pierwowzoru. $\mathrm{W}$ tym przypadku „,człowiek nie tworzy niczego nowego pod słońcem”. Na ile jednak ta argumentacja jest spójna $\mathrm{z}$ dotychczasową linią orzeczniczą w zakresie sekwencji DNA, gdzie uznaje się, że kopia w postaci cDNA posiada inną charakterystykę niż pierwowzór, jest pytaniem otwartym, a odpowiedź jest zależna od przypisania wagi ewentualnym różnicom pomiędzy klonem a dawcą materiału genetycznego. Dodatkowo pobrzmiewa tu także niespójność z linią orzeczniczą opartą na rozróżnieniu, czy wynalazek jest nowy jakościowo (new in kind), czy też nowy w formie (new in degree) w rozumieniu zmiany niektórych parametrów. Klon nie różniąc się jakościowo od dawcy, stanowi jednak jego inną formę chociażby poprzez to, że posiada informację genetyczną pochodzącą od pojedynczego „rodzica”. Niewątpliwie też powstaje inaczej, bo na drodze pozapłciowej.

\section{Moralność}

Art. 29 p.w.p. zabrania udzielenia patentów na wynalazki, których wykorzystywanie byłoby sprzeczne z porządkiem publicznym lub dobrymi obyczajami. Natomiast art. $93^{3}$ p.w.p. dodaje jeszcze przesłankę moralności, jednocześnie wskazując cztery szczególne przypadki sprzeczności. Wyliczenie ma charakter przykładowy i w oparciu o klauzule generalną z art. 29 p.w.p. dozwolone jest identyfikowanie innych przypadków. ${ }^{41}$

\footnotetext{
39 "Laws of nature, natural phenomena, and abstract ideas are not patentable" 35 U.S.C. § 101.

40 Association for Molecular Pathology przeciwko Myriad Genetics, Inc. USSC 12-398.

41 Polska regulacja koresponduje tu z prawem międzynarodowym w tej dziedzinie, w szczególności EPC (art. 53a), TRIPS (art. 27.2) oraz dyrektywą biotechnologiczną.
} 
Można zadać ogólne pytanie, czy patentowanie organizmów żywych oraz materiału biologicznego pochodzącego od człowieka jest zgodne z moralnością publiczną. Odpowiedź została przesądzona właśnie przez samo uchwalenie dyrektywy i poparta odrzuceniem przez TS UE skargi Holandii zwierającej m.in. zarzuty niezgodności z podstawowymi prawami człowieka. ${ }^{42}$ Wobec powyższego pozostaje skupienie się na interpretacji wskazanych ustawowo egzemplifikacji niezgodności z moralnością, gdzie szczególną rolę odgrywają wynalazki biotechnologiczne wykorzystujące materiał genetyczny człowieka. Nie wiadomo, czy na poziomie europejskim istnieje wspólne rozumienie moralności, ale przynajmniej w zakresie możliwości patentowania ludzkich embrionów i klonowania ludzi panuje zgodność. Powyższe wspomaga podejście przyjęte przez EPO, nie dopuszczające patentowania, jeżeli byłoby ono sprzeczne z zasadami moralnymi przyjętymi chociażby w jednym państwie członkowskim. ${ }^{43}$ Reguła ta działa w sposób rozszerzający, zapewniając jednak spójność orzecznictwa w większym stopniu niż możliwa reguła przeciwna. O ile kategoryczne ujęcie pierwszych dwóch wyjątków $93^{3}$ p.w.p. w zasadzie przecina, ${ }^{44}$ przynajmniej na chwilę obecną, spekulacje, to sprawa stosowania embrionów ludzkich do celów przemysłowych wymagała uściślenia w zakresie pojęcia „embrion”. Dzięki dwóm niedawnym wyrokom TS UE ${ }^{45}$ otrzymaliśmy względną pewność, że elementem konstytutywnym embrionu jest ,wrodzona zdolność rozwinięcia się w jednostkę ludzką", którą posiadają zapłodnione komórki jajowe. Natomiast niezapłodnione komórki jajowe pobudzone do podziału w wyniku partenogenezy takiej zdolności nie mają, ${ }^{46}$ jak powiedział TS UE w późniejszym wyroku (International Stem Cell Corporation), zmieniającym wcześniejszą interpretację w sprawie Brustle. W tym zakresie wyrok jest korzystny dla przemysłu biotechnologicznego, ale nadal pozostawia otwarte pytanie natury etycznej. Możliwe jest bowiem zakazanie patentowania także tego typu zarodków (partenot) w oparciu o ogólną przesłankę porządku publicznego lub moralności. ${ }^{47}$

Warto jednak podkreślić, że ,uregulowania zawarte w prawie własności przemysłowej jedynie zakazują udzielania patentów na sposoby klonowania ludzi, nie

Wyrok TS UE w sprawie C-377/98 Kingdom of the Netherlands przeciwko European Parliament and Council of the European Union.

H.P Götting, Patents for biotechnological inventions and morality, artykuł przeznaczony do publikacji w księdze pamiątkowej śp. prof. M. du Valla (wrzesień 2015).

Niedopuszczalny jest jakikolwiek sposób zmierzający do klonowania człowieka, włącznie z technikami dzielenia embrionu (pkt 41 dyrektywy biotechnologicznej). Modyfikacja tożsamości genetycznej linii zarodkowej człowieka też powinna być rozumiana szeroko, dzięki czemu nie jest możliwe „mieszanie” materiału genetycznego i patentowanie tzw. chimer, ani też patentowanie sposobów terapii genowej dotyczącej ludzkich komórek rozrodczych (M. du Vall, Prawo patentowe..., op. cit., s. 381).

International Stem Cell Corporation C-364/13 oraz Brüstle przeciwko Green Peace C-34/10.

Ostateczne ustalenie w świetle zasad nauki należy tu do sądu krajowego.

A. Nowicka, Wynalazek biotechnologiczny jako przedmiot patentu. Prawnopatentowy status ludzkich embrionalnych komórek macierzystych, artykuł przeznaczony do publikacji w księdze pamiątkowej śp. prof. M. du Valla (wrzesień 2015). 
zakazując zarazem tego typu eksperymentów". ${ }^{48}$ Zakaz patentowania często jest bowiem mylony w odbiorze społecznym z brakiem legalności przeprowadzania niektórych badań w tym zakresie, a prawo patentowe nie jest odpowiednim miejscem do wprowadzania ewentualnych zakazów.

\section{Podsumowanie}

Wskazane powyżej zagadnienia nie wyczerpują kontrowersji związanych z udzielaniem ochrony na wynalazki biotechnologiczne. Ich specyfika znajduje swój wyraz także w obowiązywaniu zakazu patentowania odmian roślin bądź ras zwierząt w sytuacji, gdy zostały one uzyskane sposobami mikrobiologicznymi; ${ }^{49}$ wymogu dostatecznego ujawnienia wynalazku i stosowania depozytu materiału biologicznego; opisu wynalazku (także w relacji do zastrzeżeń), jak i samego zakresu ochrony jakże specyficznie uregulowanego w art. $93^{5}$ p.w.p. Wydaje się jednak, że najpoważniejsza debata tocząca się od lat dotyczy granic dopuszczalności patentowania szczególnych postaci wynalazków biotechnologicznych. Artykuł poruszał wyłącznie kwestie prawnej interpretacji przesłanek patentowalności i wyłączeń spod tego zakresu, bez oceny innych argumentów natury pozaprawnej. A w szczególności właśnie one podgrzewają temperaturę wokół toczącej się debaty. $Z$ jednej strony mamy spory etyczne, toczone także z użyciem argumentów z perspektywy idealistycznej i religijnej, wymogów ochrony środowiska naturalnego, także odwołujących się do społecznych i kulturowych uwarunkowań oraz wolności prowadzenia badań naukowych. Z drugiej strony mamy silne argumenty natury ekonomicznej, które być może posiadają istotniejszy realny wpływ na kształtowanie się polityki patentowej w tym zakresie. Należy przyznać, że te ostatnie odwołują się do założeń systemu patentowego, który powinien zapewnić skuteczne środki ochrony działań innowacyjnych, jednocześnie je stymulując poprzez zabezpieczenie uzyskania finansowej rekompensaty. Co nie znaczy, że również w sferze ekonomicznej nie dostrzega się pewnych dysfunkcji systemu, dla przykładu jak: zapewnienie nieproporcjonalnie szerokiego zakresu wyłączności w stosunku do innowacyjnego wkładu dla społeczeństwa; gąszcz nakładających się wzajemnie zastrzeżeń patentowych zaciemniających obraz ochrony, czy też bezrefleksyjne udzielanie ochrony na wyniki wątpliwych badań naukowych. ${ }^{50}$ Komisja Europejska broniąc dyrektywy biotechnologicznej, podkreśliła między innymi pozytywny skutek w postaci utrzymania w Europie przemysłu

48 M. Lipiński, Regulacje prawne dotyczące klonowania w prawie polskim de lege lata na tle unormowań europejskich „Palestra” 2007, nr 5-6, s. 53.

49 Na ten temat zob. K. Felchner, Ż. Pacud, Ochrona roślin w prawie własności przemysłowej-porównanie ochrony patentowej i ochrony wyłącznym prawem hodowcy, „Europejski Przegląd Sądowy” 2015, nr 1, s. 26 i n.

50 Zob. Disscusion Paper on The Ethics of Patenting DNA przygotowany przez Nuffield Council on Bioethics, dostępny na http://nuffieldbioethics.org/wp-content/uploads/2014/07/The-ethics-of-patenting-DNA-a-discussion-paper.pdf (data dostępu: 11.09.2015 r.). 
biotechnologicznego zdolnego sprostać konkurencyjnym wyzwaniom zza oceanu, ${ }^{51}$ które otwierając się na wynalazki biotechnologiczne dały silny bodziec do rozwoju przemysłu.

51 Raport KE, Development and implications of patent law in the field of biotechnology and genetic engineering $\operatorname{COM}(2002) 545$ final. 


\section{CONTROVERSY SURROUNDING THE PATENTABILITY OF BIOTECHNOLOGICAL INVENTIONS}

In this article the patentability of biotechnological invention is discussed focusing on some controversies still arising in that area. Beginning from a few landmark decisions permitting broad patenting of biotechnological inventions both in Europe and USA (albeit not issued concurrently) the answer for the patentability of living organisms has been made obvious. The assessment should no longer rely on the distinction that the subject matter of the invention is alive. The above has confirmed the biotechnology directive enacted in 1998. The directive should not be perceived as the sufficient tool for regulation of patentability of biotechnological invention. In the last ten years patent offices across the world are facing several important questions regarding more specific interpretation of the requirements of patentability in that context. The article shows how the concept of novelty, inventive step (non-obviousness) and industrial capability is understood in the field of biotechnology, with particular focus on gene patents. Also the line between invention and discovery is commented. As a separate issue, the exclusion from patentability due to contradiction with morality principles is briefly introduced.

Słowa kluczowe: biotechnologia, patenty, zdolność patentowa, przesłanki patentowalności, wyłączenia patentowania, odkrycia, moralność, gen, DNA, komórki macierzyste

Keywords: Biotechnology, patents, patentability requirements, limitations of patenting, discovery, morality, gene, DNA, stem cells 